\title{
Enhancing Building Performance: The Role of the Facilities Manager at the Design Stage
}

\author{
Papa Yaw Attobrah \\ Development and Maintenance Unit, \\ University of Mines and Technology \\ Tarkwa, Ghana \\ pyattobrah@umat.edu.gh
}

\author{
James Frimpong-Asante \\ Department of Land Economy, \\ Kwame Nkrumah University of \\ Science and Technology, \\ Kumasi, Ghana
}

\author{
Mustapha Attah \\ Development and Maintenance Unit, \\ University of Mines and Technology \\ Tarkwa, Ghana
}

\begin{abstract}
Facilities management has emerged as a profession and practice that seeks to efficiently and effectively integrate people with the built environment in order to enable organisations fulfil their objectives. Central to the activities within the built environment are buildings which are pivotal in facilitating the realisation of the facilities management function. However, the process in procuring buildings as a product relegates the facilities management function to the hand-over stage, when they are brought in to ensure that buildings operate efficiently to achieve its purpose. The efficient management of buildings to ensure that they integrate well with people, process and technology to perform as required necessitates the facilities manager's involvement at the onset of the building development process in order to understand the rationale for certain decisions that culminated in the product being handed over for management. This study examines the role of the facilities manager at the design stage and how their involvement can enhance the performance of buildings. A qualitative research approach was adopted in the conduct of this study whilst the use of semistructured interviews was deployed to solicit information from experts involved in the building development process as well as practitioners of facilities management. These were analysed based on their thematic content. The study identified that the involvement of facilities managers at the various stages of the design process as outlined by the RIBA Work Plan of 2013 has a consequential effect in enhancing the performance of buildings during its life cycle.
\end{abstract}

\section{Keywords}

Facilities Management, Building Performance, Design Stage,

\section{INTRODUCTION}

Buildings provide various benefits to organizations and individuals in the performance of activities to achieve their intended objectives. They provide a secure environment that enables the processes needed to be implemented to achieve organizational and individual goals permissible. Buildings are designed to meet specific objectives as well as performance criteria, however the realization of these expectations are hardly met due to the seeming gap between the producers of the product [building design team] and the end users of the product [Wang et. el., 2013]. The design phase of a building relates to the process of providing all the necessary information required to facilitate its construction in order to meet the requirements of the client as well as public expectations in terms of their safety, health and welfare [Rickets and Merritt, 2001]. Facilities management has evolved to ensure that all components of a building integrate well to provide a conducive environment that supports the activities of an organization. It is therefore sufficing to say that the facilities manager is well positioned to better appreciate how the various components of buildings integrate to provide its needed expectations hence the need to be involved in the conceptualization and the design process of buildings. Given the essential role of the facilities manager in ensuring that buildings perform at optimal levels for user satisfaction, this research seeks to analyse the role of the facilities manager within the context of the design phase and how these could be translated to enhance the performance of buildings during its life cycle.

\section{THE CONCEPT OF BUILDING PERFORMANCE AND FACILITIES MANAGEMENT}

Buildings are essentially constructed to facilitate and support the activities for which they were intended [Villanueva et. al., 2017], however, more often than not they fail to meet the varied and conflicting expectations of its many users [Sustainable Energy Research Group, 2006] due to the subjectivity inherent with determining the fulfilment of its requirements. Moreover, buildings are designed to satisfy different performance objectives depending on the purpose for which they are required [Lago et. al., 2018]. For instance, to the municipal authorities, compliance with codes would be the benchmark whereas energy efficiency would be for sustainability whilst to the FM the ease of accessibility for maintenance and operations leading to optimum utilisation. Similarly, IEA Annex 21 [2016] discusses the concept of performance in relation to building energy simulation which requires an expression of multivariate building performance through the establishment of a representation of a base case design, model calibration, the evaluation of boundary conditions, integrated simulation, etc. The concept and context of ascertaining 
a buildings' performance remains an elusive construct due to the varied interpretations, perspectives and experiences of its users [Sustainable Energy Research Group, 2006]. de Wilde[2017] explains that the complexity associated with defining building performance is due to the many characteristics of the built environment which includes the long life span of buildings, with its many phases, the many different stakeholders, the many systems and components that are used in buildings, the wide range of challenges in the environmental, economic, health and wellbeing that buildings have to respond to, the organizational structure of the construction industry, underlying tensions between the fields of architecture and engineering, and others. The concept of building performance therefore ensures that the various systems that comprises the built form work together effectively to achieve its intended use and aligns with IFMA's definition of facilities management as "a service provision that encompasses multiple disciplines to ensure the satisfactory functionality of the built environment by integrating people, place, process, technology and environment”. Buildings, facilities, and people interrelate to facilitate organizational performance [Amaratunga and Baldry, 1998] and that the continued sustenance of the interrelationship hinges on the proper performance of buildings. Pilanawithana and Sandanayake [2016] also assert that FM works to integrate an organisations human and other resources with its built environment in other to support its objectives and thus has the responsibility to ensure that buildings perform optimally to achieve an organisations primary objective. Moreover, the age long concept of facilities management has been synonymous with the operations and maintenance phase of buildings [Jensen, 2009] which is geared at ensuring the optimal performance of buildings. It is sufficing therefore to say that the services of the FM are synonymous with the achievement of effective building performance.

\subsection{Definitions of Building Performance}

Douglas [1996] postulates that building performance denotes the physical performance characteristics and how it integrates with its parts to contribute to fulfilling the functions of its intended use. Building performance is defined by Williams [2006] as a building's ability to fulfil the functional and financial requirements of clients and users as well as the physical and financials characteristics of the fabric and its elements. Corry et. al. [2014] also defines building performance as "delivering the functional intent of each zone of the building while accounting for the energy and cost of delivering this functional intent. de Wilde [2018] asserts that "building performance is a concept that describes, in a quantifiable way, how well a building and its systems provide the tasks and functions expected of that building". These definitions seek to interpret the concept of building performance in relation to a building as an amalgamation of various parts that integrate to deliver on its expected function and suggests that the process of evaluation as being procedural. The difficulty in assessing the performance of buildings based on these perspectives are its subjectivity in relation to the basic usability for the end users which usually conflicts with the operational and maintenance aspects for the professional users like facilities managers and the service staff [Jensen et. al., 2009]. Other authors define the subject with reference to the discipline of interest, for instance, Mustafa [2017] asserts that building performance is the systematic evaluation of its efficiency in supporting the predicted activities for which it was intended.
Alternatively, Yekrangnia and Arian [2019] relates building performance to the safety afforded to occupants as well as the ease with which a building can withstand seismic activity. This interpretation of building performance rather considers the extent to which a building can withstand damage, ease of restoration, economic, architectural significance as well as the larger impact on society rather than the fulfilment of any other requirements. Building performance is therefore a central concept in ensuring that buildings meet the requirements for which they are built and that they are fit for purpose. Gopikrishnan and Paul [2018] also views building performance as the failure of meeting a specific performance level expected by end users. American Council for Energy Efficiency Economy [ACEEE, ND] on the other hand postulate that building performance aims to improve the energy performance of buildings in terms of energy efficiency, comfort and productivity. Building performance plays a role in all stages of the building life cycle, from developing the building brief to design and engineering, construction, commissioning, operation, renovation and ultimately deconstruction and disposal. Moreover, CIBSE [2016], a UK professional body that supports the science, art and practice of building services engineering, identified FM as the best profession to manage and optimize the defined activities and resources to achieve corporate objectives.

\subsection{Determinants of Building Performance Levels}

In spite of the absence of a concise and working definition and the contribution of different disciplines in determining building performance within existent literature, there seems to be an agreeable trend that exists in the various interpretations. de Wilde [2017] argues that the notion of building performance predates the era of the millennium and that in disciplines like architecture the concept of "firmness, commodity and delight" expressed by Vitruvius was in response to how architectural form considered performance in its evolution. de Wilde [2017] emphasises that the key notion of performance that stems from the existent literature is that performance is a concept that lives on the interface of user requirements and the behaviour of technical solutions, and which captures how well the "solutions" meet the "demands". Bordass et. al. [2001] asserts that determining performance indicators has been the source of interest in the many disciplines that characterizes the building industry, however, due to the divergent perspectives these indicators more often conflict with each other. For instance, Slopek [2013] suggests that the age, size of buildings, efficiency of features, management, monitoring, ongoing commissioning and occupants' engagement as factors that tend to impact on building performance. Ibem et. al. [2013] on the other hand notes that the process of evaluating building performance takes cognizance of the architectural, functional, technical, and economic value of buildings. Bordass et. al. [2005] postulates that irrespective of the criterion used to assess building performance, user satisfaction or post occupancy evaluation provides a better indicator. Similarly, Preiser and Visher [2005] corroborates that occupants' perspectives and requirements summed up in post occupancy evaluation facilitates the determination of building performance. Irrespective of the perspective from which building performance is being evaluated, there exist a commonality in literature that permeates the instrument of assessment. de Wilde [2018] suggests that collectively, building performance can fundamentally be expressed and assessed from three perspectives or views and these are engineering view, process view and arts and humanities view. 
The engineering view relates to how well a building fulfils its functions with respect to the quality inherent in its functions, the workload capacity which de Wilde [2018] explains relates to how much a building can do as well as resource saving in terms of energy performance. The process view considers buildings as an output of a process and relates to the sequence of construction activities and expressed in terms of the management of cost, time, quality, safety, waste reduction and customer satisfaction. The arts and humanities view focuses on building performance in terms of creativity, interpretation, communication, embodiment, enchantment and movement. This view of performance relates to design approaches towards building performance.

The focus of this research would predominantly be focused on the engineering perspective as well as the arts and humanities perspective of building performance.

\subsection{The Design Stage of Buildings}

The design stage of a building consists of a series of interrelated activities that leads to the realization of an intended functional object; a building. It is the process of translating an idea into a visual and buildable form. Bragança et. al. [2014] affirms that the design stage relates to a set of consecutive actions that guides the development process of buildings and further suggests that these actions facilitates the realization of design documentation to enable construction. Kalay (1999) discusses this stage with the famous architectural notion that 'form follows function' and relates to building design as problem solving or as puzzle making, noting that performance evaluation is needed to give direction to the design process. The design stage is also presented as a special kind of decision making that discusses the stage in relation to designing for people, design as decision making, the use of resources, spatial elements, the bounding of spatial elements, the grouping of spatial elements.Hopfe et. al. [2006] articulates the design process as a series of operations undertaken to solve a design problem. Merritt and Ricketts [2001] also postulate that the design stage entails the process of providing all the necessary information required to facilitate the construction of a building to meet the needs of owners as well as satisfy the safety, health and welfare of the public. Fadamiro and Bobadoye [2006] asserts that the design stage in the building industry has considerable impact on the success of subsequent processes in the construction of projects and further suggests that a large percentage of defects in buildings arise through decisions or actions taken in the building development process. Similarly, Knotten et. al.[2015] suggests that much of the issues that pertains to building performance stems from poor management of the design phase. These assertions therefore make it imperative for the consideration of building performance in relation to the design stage as it offers the basis for subsequent decision making in the building development process. Literature from existent studies suggests that the design stage consists of a series of actions, activities, which are interrelated and consecutive and has a measurable objective of delivering a specific outcome; a building. The various phases ascribed to the design stage has varied interpretations from different authors. For instance, Fadamiro and Bobadoye [2006] affirms that "the breakdown of the design process into stages varies considerably across studies both in terms of content and the names given to each stage" and suggests the division of the process into four [4] distinct stages: [1] inception and brief collection, [2] detail design and working drawings, [3] execution stage, and [4] feedback from operations.

Knotten et. al. [2015] also concedes that the design process as consisting of a series of phases and cites stages 1 to 4 of the RIBA 2013 Plan of Work as consisting of the design phase. The Bronco Project Process [ND] suggests that Design Phase consists of four sub-phases: Programming Phase, Schematic Design Phase, Design Development Phase, and Construction Document Phase. In the context of this study, the design stage aligns with stages 0 to 4 of the RIBA Plan of Work 2013 as indicated in Figure.1 below. British Institute of Facilities Management [BIFM, 2016] affirms that the RIBA Plan of work 2013 provides a comprehensive framework that leads the design process and integrates various disciplines from across the built environment and end user perspectives in the building development process.

In Figure 1 below, RIBA [2013] outlines 8 stages for the building development process, however, this study primarily focuses on the first five stages [0-4] which comprises the preconstruction or design stage of a building. Although presented sequentially, the RIBA 2013 stages that constitutes the design phase is an iterative process and consists of:

\section{Stage 0 - Strategic Definition \\ Stage 1 - Preparation and Brief \\ Stage 2 - Concept Design \\ Stage 3 - Developed Design \\ Stage 4 - Technical Design}

The first stage of the process, the strategic definition [RIBA, 2013] outlines the appraisal of the idea in terms of considerations for alternate sites, whether to build, extend or refurbish and the viability of the proposal. Oliveira et. al. [ND] refers to this stage as the information gathering, analysis and synthesis phase of the design process. Knotten et. al. [2015] asserts that the preparation and brief stage entails the stage where inputs for the rest of the building process are collated alongside a variety of key decisions that have far reaching consequences on the subsequent processes of building development. It is at this stage that the objectives of the project as well as the identification of key stakeholders and the composition of the team required to implement the process are determined [RIBA, 2013]. This phase presents the greatest opportunity to obtain high performance buildings, but pertinent information is needed for designers to be able to deal with multidisciplinary and contrasting objectives. At the concept design stage, information gathered in the previous stage is processed to create design options and alternatives that best suits clients' requirements. The developed design stage enables further development of the most suitable design option that best suits the clients brief. Pfeifer [2009] asserts that the stage affords decisions to be made in relation to the impact of design on performance, reliability and costs. The technical design stage entails the development of the detailed design in sufficient detail to enable construction. The technical details and specifications for architectural, structural, and all other information that enables the commencement of the construction phase are catered for in this process [RIBA 2013]. 


\begin{tabular}{|c|c|c|c|c|c|c|c|c|}
\hline $\begin{array}{l}\text { niDh } \\
\text { Planof } \\
\text { Work } \\
2013\end{array}$ & $\begin{array}{l}\text { Strategic } \\
\text { Definition }\end{array}$ & $\begin{array}{l}1 \\
\text { Preparation } \\
\text { and Brief }\end{array}$ & $\begin{array}{l}2 \\
\text { Concept } \\
\text { Design }\end{array}$ & $\begin{array}{l}3 \\
\text { Developed } \\
\text { Design }\end{array}$ & $\begin{array}{l}\text { Technical } \\
\text { Design }\end{array}$ & Construction & $\begin{array}{l}\text { Handover } \\
\text { and Close Out }\end{array}$ & In Use \\
\hline $\begin{array}{l}\text { Core } \\
\text { Objectives }\end{array}$ & $\begin{array}{l}\text { Identify client's Business } \\
\text { Case and Strategic Brief } \\
\text { and ather core project } \\
\text { requirements. }\end{array}$ & $\begin{array}{l}\text { Develop Project Objectives, } \\
\text { including Quality Objectives } \\
\text { and Project Outcomes, } \\
\text { Sustainability Aspirations, } \\
\text { Project Budget, other } \\
\text { parameters of Constraints and } \\
\text { develap Intital Project Briet. } \\
\text { Undertake Feasibility Studies } \\
\text { and revew of Site Information. }\end{array}$ & 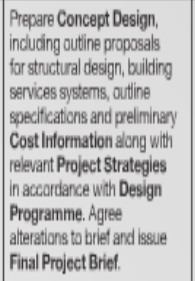 & $\begin{array}{l}\text { Prepare Developed Design, } \\
\text { including coordinated and } \\
\text { updated proposads for } \\
\text { structural design, building } \\
\text { services systems, outline } \\
\text { specifcatians, Cost } \\
\text { Information and Project } \\
\text { Strategies in accordance with } \\
\text { Design Programme. }\end{array}$ & 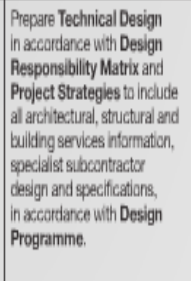 & $\begin{array}{l}\text { Offsite manufacturing and } \\
\text { onsite Construction in } \\
\text { accordance inth Construction } \\
\text { Programme and resalution of } \\
\text { Design Queries from site as } \\
\text { they arse. }\end{array}$ & $\begin{array}{l}\text { Hendover of bulding and } \\
\text { conclusion of Building } \\
\text { Contract. }\end{array}$ & $\begin{array}{l}\text { Undertake In Use services } \\
\text { haccordance with } \\
\text { Schedule of Services. }\end{array}$ \\
\hline $\begin{array}{l}\text { Procurement } \\
\text { "Varable task tat }\end{array}$ & $\begin{array}{l}\text { Inital cansiderations for } \\
\text { assembling the project team. }\end{array}$ & $\begin{array}{l}\text { Prepare Project Roles Table } \\
\text { and Contractual Tree and } \\
\text { contrue assembing the } \\
\text { project team. }\end{array}$ & \multicolumn{3}{|c|}{ 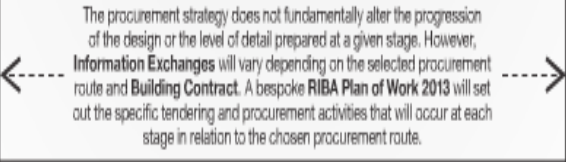 } & $\begin{array}{l}\text { Administralion of Building } \\
\text { Contract, incluading regular } \\
\text { site inspections and review } \\
\text { of progress. }\end{array}$ & $\begin{array}{l}\text { Conclude administration of } \\
\text { Building Contract. }\end{array}$ & \\
\hline $\begin{array}{l}\text { Programme } \\
\text { Variable task bar }\end{array}$ & Estabish Project Programme. & Review Projoct Programme. & Review Projoct Programme. & \multicolumn{3}{|c|}{ 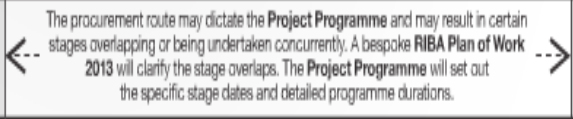 } & & \\
\hline $\begin{array}{l}\text { (Town) Planning } \\
\text { "Varable task tar }\end{array}$ & Pre appication discussions. & Pre application discussions. & \multicolumn{3}{|c|}{$\begin{array}{l}\text { Plarning applicalions are typically made using the Stage } 3 \text { output. } \\
\qquad-. .- \text { A bespoke RiBA Plan of Work } 2013 \text { will identily when the planning } \\
\text { application is to be made. }\end{array}$} & & & \\
\hline $\begin{array}{l}\text { Suggested } \\
\text { Key Support } \\
\text { Tasks }\end{array}$ & $\begin{array}{l}\text { Review Feedback from } \\
\text { previous prejects. }\end{array}$ & $\begin{array}{l}\text { Prepare Handover Stratogy } \\
\text { and Risk Assessments. } \\
\text { Agree Schedule of Services, } \\
\text { Design Responsibility } \\
\text { Matrix and Information } \\
\text { Exchanges and pepare } \\
\text { Project Execution Plan } \\
\text { including Tochnology and } \\
\text { Communication Stratogios } \\
\text { and corsiderdition of Commmon } \\
\text { Standards to be used. }\end{array}$ & $\begin{array}{l}\text { Prepare Sustainability } \\
\text { Strategy, Maintenance and } \\
\text { Operational Strategy and } \\
\text { review Handover Strategy } \\
\text { and Risk Assessments. } \\
\text { Undertake third party } \\
\text { consultations as required } \\
\text { and any Research and } \\
\text { Development aspects. } \\
\text { Review and update Project } \\
\text { Execution Plan. } \\
\text { Consider Construction } \\
\text { Strategy, including offsite } \\
\text { fabrication, and develop Health } \\
\text { and Saftety Strategy. }\end{array}$ & $\begin{array}{l}\text { Review and update } \\
\text { Sustainability, Maintenance } \\
\text { and Operational and } \\
\text { Handover Strategies and } \\
\text { Risk Assessments. } \\
\text { Undertake third party } \\
\text { consultations as required } \\
\text { and canclude Research and } \\
\text { Development aspects. } \\
\text { Revew and update Project } \\
\text { Execution Plan, Induding } \\
\text { Change Control Procedures. } \\
\text { Review ard update } \\
\text { Construction and Health and } \\
\text { Salety Strategies. }\end{array}$ & $\begin{array}{l}\text { Review and update } \\
\text { Sustainability Maintenance } \\
\text { and Operational and } \\
\text { Handover Strategies and } \\
\text { Risk Assessments. } \\
\text { Prepare and submit Building } \\
\text { Regulations subrrission and } \\
\text { any other third party } \\
\text { silomissions requirng consent. } \\
\text { Feview and update Project } \\
\text { Execution Plan. } \\
\text { Review Construction } \\
\text { Strategy, including } \\
\text { sequencing, and update } \\
\text { Health and Salety Strategy. }\end{array}$ & 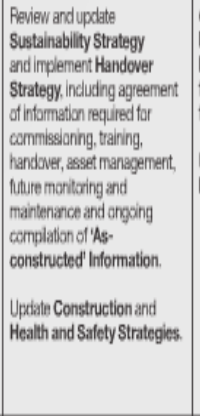 & $\begin{array}{l}\text { Carry out activities isted in } \\
\text { Handover Stratogy including } \\
\text { Feedback for use durng the } \\
\text { future life of the building or on } \\
\text { future projects. } \\
\text { Updating of Project } \\
\text { Infornation as required. }\end{array}$ & $\begin{array}{l}\text { Conclude activites listed } \\
\text { in Handover Strategy } \\
\text { including Post-occupancy } \\
\text { Evaluation, review of Project } \\
\text { Performance, Project } \\
\text { Outcomes and Research } \\
\text { and Development aspects. } \\
\\
\text { Updating of Project } \\
\text { Information, as required, in } \\
\text { resporse to ongoing clent } \\
\text { Foedback untill the end of the } \\
\text { bulding's llite. }\end{array}$ \\
\hline $\begin{array}{l}\text { Sustainability } \\
\text { Checkpoints }\end{array}$ & $\begin{array}{l}\text { Sustainability } \\
\text { Checkpoint - } 0\end{array}$ & $\begin{array}{l}\text { Sustainability } \\
\text { Checkpoint - } 1\end{array}$ & $\begin{array}{l}\text { Sustainability } \\
\text { Checkpoint - } 2\end{array}$ & $\begin{array}{l}\text { Sustainability } \\
\text { Checkpoint -3 }\end{array}$ & $\begin{array}{l}\text { Sustainability } \\
\text { Checkpoint }-4\end{array}$ & $\begin{array}{l}\text { Sustainability } \\
\text { Checkpoint }-5\end{array}$ & $\begin{array}{l}\text { Sustainability } \\
\text { Checkpoint }-6\end{array}$ & $\begin{array}{l}\text { Sustainability } \\
\text { Checkpoint - } 7\end{array}$ \\
\hline Information & Strategic Brief. & Initial Project Briet. & $\begin{array}{l}\text { Concept Design including } \\
\text { authe structural and building }\end{array}$ & \begin{tabular}{|l|} 
Developed Design, including \\
the coordinated architectura,
\end{tabular} & $\begin{array}{l}\text { Completed Technical Design } \\
\text { of the project. }\end{array}$ & \begin{tabular}{|l} 
'As-constructed' \\
Information.
\end{tabular} & $\begin{array}{l}\text { Updated 'As-constructed' } \\
\text { Information. }\end{array}$ & $\begin{array}{l}\text { 'As-constructed' } \\
\text { Information updated }\end{array}$ \\
\hline
\end{tabular}

Figure 1: RIBA Plan of Work 2013

\subsection{The Facilities Manager and the Building Development Process}

An objective of this study is to articulate for a definitive role of the facilities manager at the design stage of the building development process and to achieve this, the various roles of FM as exists in previous studies needs to be evaluated.

Facilities management is an emerging discipline in the built environment industry which focuses on the efficient and effective integration of buildings and their systems, people, processes and technology in order to enhance an organization's effectiveness [Enoma, 2005]. McAuley et. al. [2012] asserts that facilities management has evolved to address the inadequacies that characterize the built environment particularly to enable organizations derive optimal benefits from their investments in constructed facilities. Brown et. al. [2001] argue that the business expertise of the facilities manager together with the core skills related to managing operational building assets, mean that it is reasonable to suggest that facilities management plays a significant role in the development process of buildings.

In spite of the of the acknowledged role of the facilities manager in the building development process, their involvement has been the subject of varied perspectives leading to a process of not thoroughly being integrated enough [Cousins et. al., 2005].

Brown et. al. [2001] suggest that the process orientated skills of the facilities manager, together with their direct knowledge of 
the operational requirements made of building assets, mean that they should be appointed to the lead roles in the building procurement process. Enoma [2005] postulates on the need for a paradigm shift of perceiving FM at the operations stage to a more strategic role of the procurement process and the point at which their contributions to the decision making process will be most valuable to the design team. Jensen et. al.[2009] argue for the integration of FM in the various facets of the building development process and suggest the adoption of the concepts of front end and back end knowledge transfer in order to attain optimal benefits from FM. De Silva [2011] asserts that the integration of facilities management in building development facilitates less maintainability issues at the operations stage and value proposition for building owners. McAuley et. al. [2012] on the hand asserts that the early adoption of facilities management in the development process has the potential of promoting sustainability and a reduction in construction costs achieving optimal life cycle benefits for the constructed facility. Similarly, Potkany et. al. [2015] shares that positioning the FM in the preinvestment phase has the tendency to influence operational costs in the future. In instances when the facilities managers are involved early in the design stage, their involvement are often hampered by challenges of coordinating the requirements of both the client and various professionals [Pitt et. al., 2005]. It is argued that facilities manager's role at the design stage is not confined to the understanding of simple designs, but rather consists of interpreting complex designs for the purpose of functional efficiency.

\subsection{Conceptual Framework}

This study seeks to interpret Building Performance from a holistic perspective rather than ascribing particular attributes of the construct for evaluation. In the light of the objective of this research which seeks to articulate a role for the FM at the design stage, the conceptual interpretation of building performance would be from a performance based perspective. The performance based perspective of building performance postulates "working in terms of ends rather than means". Szigeti and Davis [2005] explains that the choices and decisions made with regards to the building commences with "required performance-in-use rather than as a response to required functions. An illustration of the concept is illustrated in Figure 2 below. The conceptual framework below illustrates the rationale for articulating for the involvement of the FM in the design process, that is, to procure a performance oriented building.

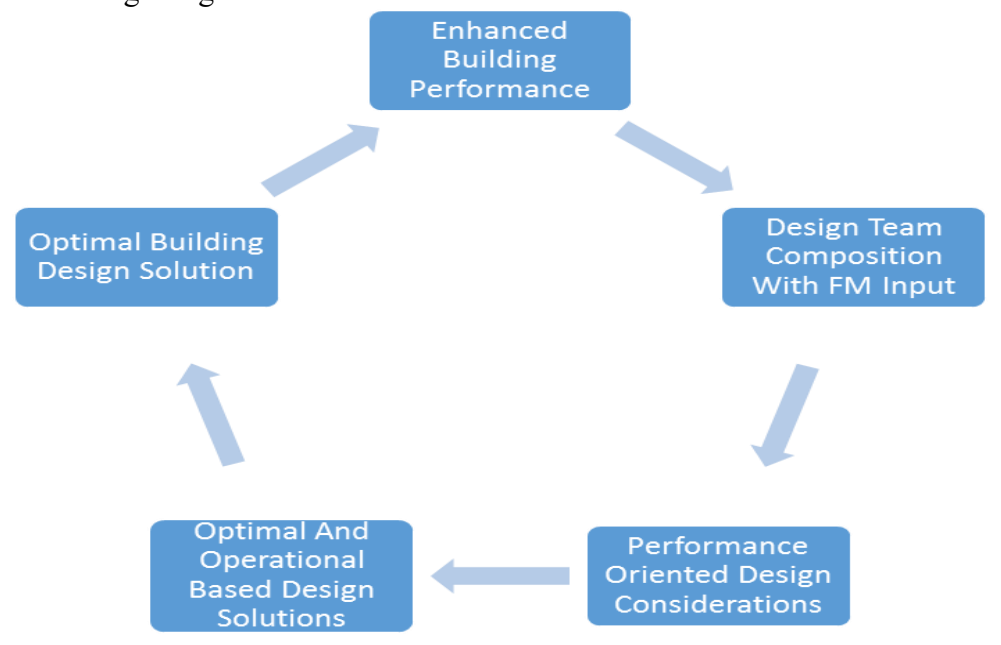

Source: Author (2019)

Figure 2: Conceptual Framework illustrating the research approach

\section{RESEARCH METHODOLOGY}

The study seeks to explore and articulate how the facilities manager's role at the design stage could be harnessed to influence the performance of buildings. The objective of this research is to understand phenomenon within a specific managerial context, qualitative methods are to be applied in the collection and analysis of data in order to obtain a better understanding and interpretation. Easterby-Smith et. al. [2012], Labaree [2009] explains that qualitative methods provides a better understanding of real world experiences in specific contextual settings where the topic under investigation cannot be subjected to manipulation. Similarly,
Jones [2004], Labaree [2009] asserts that issues that boarders on management are better understood and addressed with a qualitative research approach. In order to articulate a definitive role for the facilities manager at the design stage to enhance building performance, the use of semi structured interviews were employed to obtain relevant information from experts within the building industry.

\subsection{Sampling Methods}

For the aim of the study to be achieved, Ayres [2019] suggests the use of purposive sampling which provides a non-probability 
selection based on characteristics inherent within a specific population. This was adopted to obtain knowledgeable and verifiable information from practitioners with expertise in the building development process and particularly conversant with the design stage and building performance in order to fulfil the research objectives and answer the research questions.

\subsection{Determination of Sample Population}

In determining the sample for the study, the following criteria was employed.

- Facilities officers/ managers from Accra and West Hills Malls [malls with at least 36 months' operational experience]

- Facilities officer/ manager of a privately owned bank with in-house facilities management function

- Professionals from Development Office of a public university [with full consultancy and estate management functions]

- Manager of out sourced facilities services company [Primus Camp Management Services]

The objective in the choice of interview as a data collection method was to facilitate the in-depth coverage of key issues across the concepts being explored for the study.
Ritchie and Lewis [2003] asserts that in-depth interviews enable differing perspectives about a phenomenon to be obtained. Similarly, Bengtsson [2016] postulate that interviews facilitates a deeper understanding of the phenomenon under investigation.

The guide was formulated to make the conduct easier and to avoid unnecessary deviation from the topic under investigation. Also, it was to afford ease of participation and convenience for those who would not be readily available to partake in in-depth interviews for one reason or the other. The guide was categorized into 3 sections; the first section sought to obtain information on the profile of participants whilst the second section dealt with FM at the design stage and the third section focused on the FM and building performance.

\section{RESULTS}

In all a total of ten [10] respondents with various expertise in different industries were interviewed. This is in conformity with the assertion of Bengtsson [2016] that for qualitative studies, a data from sample population 1-30 respondents are sufficient, suffice that there is confidence that the research questions would be adequately addressed. The highlights of interviews conducted and analysed using thematic content analysis is summarized below. A summary of key respondents is shown in Table 1 below.

Table 1: Key Respondents Information

\begin{tabular}{|l|l|l|l|}
\hline $\begin{array}{l}\text { Interviewee } \\
\text { Code }\end{array}$ & Expertise/Profession & Industry & Work Experience And Job Description \\
\hline $\begin{array}{l}\text { Respondent 1 } \\
\text { (R1) }\end{array}$ & Facilities Officer & Banking & $\begin{array}{l}5 \text { years' experience. Facilities management } \\
\text { responsibilities. }\end{array}$ \\
\hline $\begin{array}{l}\text { Respondent 2 } \\
\text { (R2) }\end{array}$ & Architect & Architectural consultancy & $\begin{array}{l}10 \text { years' experience. Design, supervision, estimating } \\
\text { and general management of firm. }\end{array}$ \\
\hline $\begin{array}{l}\text { Respondent 3 } \\
\text { (R3) }\end{array}$ & Civil Engineer & Academic institution & $\begin{array}{l}\text { 6 years' experience. Construction supervision and } \\
\text { maintenance works. }\end{array}$ \\
\hline $\begin{array}{l}\text { Respondent 4 } \\
\text { (R4) }\end{array}$ & Quantity Surveyor & $\begin{array}{l}\text { Consultancy (building \& } \\
\text { construction) }\end{array}$ & $\begin{array}{l}15 \text { years' experience. Feasibility, pre and post contract } \\
\text { quantity surveying functions }\end{array}$ \\
\hline $\begin{array}{l}\text { Respondent 5 } \\
\text { (R5) }\end{array}$ & Architect & $\begin{array}{l}\text { Housing (government } \\
\text { agency) }\end{array}$ & $\begin{array}{l}13 \text { years' experience. Housing policy formulation and } \\
\text { housing related project management }\end{array}$ \\
\hline $\begin{array}{l}\text { Respondent 6 } \\
\text { (R6) }\end{array}$ & Facilities Manager & Property management & 4 years' experience. Building and grounds maintenance \\
\hline $\begin{array}{l}\text { Respondent 7 } \\
\text { (R7) }\end{array}$ & Camp Management & $\begin{array}{l}\text { Camp management services } \\
\text { (catering, accommodation } \\
\text { \& maintenance) }\end{array}$ & $\begin{array}{l}10 \text { years' experience as operation manager planning, } \\
\text { directing and coordinating operations }\end{array}$ \\
\hline $\begin{array}{l}\text { Respondent 8 } \\
\text { (R8) }\end{array}$ & $\begin{array}{l}\text { Facilities } \\
\text { Administrator }\end{array}$ & Property Management & $\begin{array}{l}3 \text { years' experience. Coordinates management of } \\
\text { building repairs and maintenance }\end{array}$ \\
\hline $\begin{array}{l}\text { Respondent 9 } \\
\text { R9) }\end{array}$ & Contractor & $\begin{array}{l}\text { Construction } \\
18 \text { years' experience. Construction management, civil } \\
\text { and ancillary construction works, design \& build }\end{array}$ \\
\hline $\begin{array}{l}\text { Respondent 9 } \\
\text { (R10) }\end{array}$ & Estate Manager & 12 years' experience. Estate and grounds management. \\
\hline
\end{tabular}

Source: Author's Fieldwork 
Table 2: Facilities Management and Building Design Process

\begin{tabular}{|c|c|c|}
\hline Category & Thematic Content & Theme Criteria \\
\hline $\begin{array}{l}\text { Stage of } \\
\text { Inclusivity }\end{array}$ & $\begin{array}{ll}- & \text { Brief Preparation } \\
- & \text { Concept Design } \\
- & \text { Technical Design }\end{array}$ & $\begin{array}{l}\text { Stage of } \\
\text { inclusion } \\
\text { for FM }\end{array}$ \\
\hline $\begin{array}{l}\text { Specific } \\
\text { FM Input } \\
\text { at Design } \\
\text { Stage }\end{array}$ & $\begin{array}{ll}\text { - } & \text { Specifications } \\
\text { and materials } \\
\text { selection } \\
\text { - } \\
\text { Link design to } \\
\text { operations and } \\
\text { vice versa } \\
\text { Efficient space } \\
\text { utilization } \\
\text { relate operational } \\
\text { performance to } \\
\text { project outcomes }\end{array}$ & $\begin{array}{l}\text { Influence of FM } \\
\text { at the design } \\
\text { stage }\end{array}$ \\
\hline $\begin{array}{l}\text { Value } \\
\text { Addition } \\
\text { and } \\
\text { Benefits of } \\
\text { Inclusivity }\end{array}$ & $\begin{array}{ll}- & \text { Optimal design } \\
\text { solution } \\
\text { - } & \text { Extended } \\
\text { building life } \\
\text { - } \quad \text { Value for money } \\
\text { - } \quad \text { Improved } \\
\text { building } \\
\text { efficiency (energy } \\
\text { consumption, } \\
\text { space utilization, } \\
\text { ergonomics) } \\
\text { Ease } \\
\text { maintenance of } \\
\text { Minimal } \\
\text { operational costs }\end{array}$ & $\begin{array}{l}\text { - Impact of } \\
\text { FM role at } \\
\text { the design } \\
\text { stage }\end{array}$ \\
\hline $\begin{array}{l}\text { Inhibitions } \\
\text { To FM } \\
\text { Early } \\
\text { Involveme } \\
\text { nt }\end{array}$ & $\begin{array}{ll}\text { - } & \text { Misconception of } \\
\text { FM role in } \\
\text { building } \\
\text { development } \\
\text { process } \\
\text { - Interference } \\
\text { (Conflicting ideas } \\
\text { between design } \\
\text { optimization and } \\
\text { operational } \\
\text { performance) } \\
\text { Cost implications } \\
\text { Emergent nature } \\
\text { of FM } \\
\text { Client } \\
\text { Preferences }\end{array}$ & $\begin{array}{ll} & \text { FM } \\
\text { challenges } \\
\text { in } \\
\text { achieving } \\
\text { inclusivity } \\
\text { at the } \\
\text { design } \\
\text { stage }\end{array}$ \\
\hline $\begin{array}{l}\text { Emergent } \\
\text { Issues on } \\
\text { Inclusivity } \\
\text { at Design } \\
\text { Stage }\end{array}$ & $\begin{array}{ll}\text { - } & \text { Project } \\
\text { complexity } \\
\text { - } \quad \text { Unavailability of } \\
\text { FM capacity }\end{array}$ & \\
\hline
\end{tabular}

Source: Author's Fieldwork

\subsection{Facilities Managers' and the Building Design Process}

The deployment of semi-structured open ended interview questions enabled a preliminary categorization of respondents' responses in line with the context of the questions and shown in Table 2.

\subsection{Facilities Management and Building Performance}

Based on the structure and composition of questions with respect to facilities management in achieving building performance at the design stage, broad categories were assigned to the questions. Responses elicited were then grouped and classified under themes or the context of the response. A summary of categories and the emergent content is shown in Table. 3 below.

Table 3: Impact of Facilities Management on Building Performance

\begin{tabular}{|c|c|c|}
\hline Category & Thematic Content & Theme Criteria \\
\hline $\begin{array}{l}\text { Building } \\
\text { performance } \\
\text { indicators }\end{array}$ & $\begin{array}{ll}- & \text { Functionalit } \\
\text { y } \\
\text { - } & \text { Utilization } \\
- & \text { Structural } \\
\text { stability } \\
\text { - } \\
\text { safety of } \\
\text { occupants }\end{array}$ & 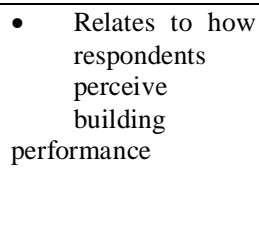 \\
\hline $\begin{array}{l}\text { Current FM } \\
\text { contribution }\end{array}$ & $\begin{array}{ll}\text { - } & \text { Efficient } \\
\text { space } \\
\text { utilization } \\
\text { - } & \text { Ensures } \\
\text { efficient } \\
\text { building } \\
\text { operation }\end{array}$ & $\begin{array}{ll}\text { Practical } \\
\text { demonstration } \\
\text { of FM to BP in } \\
\text { a life project of } \\
\text { respondents. }\end{array}$ \\
\hline $\begin{array}{l}\text { Hindsight } \\
\text { contribution }\end{array}$ & $\begin{array}{ll}- & \text { Poor } \\
& \text { workflow } \\
- & \text { Inappropria } \\
\text { te } & \\
\text { specificatio } \\
\mathrm{n} \quad \text { (early } \\
\text { deterioratio } \\
\mathrm{n} \quad \text { of } \\
\text { building } \\
\text { elements) } \\
-\quad \text { Design } \\
\text { efficiency } \\
\text { Cost saving } \\
\text { (on } \\
\text { alterations) }\end{array}$ & $\begin{array}{ll}- & \text { Adverse } \\
\text { impacts on BP } \\
\text { due to exclusion } \\
\text { of FM in BDP }\end{array}$ \\
\hline $\begin{array}{l}\text { Limitations Of } \\
\text { FM } \\
\text { Involvement In } \\
\text { Achieving } \\
\text { Building } \\
\text { Performance }\end{array}$ & 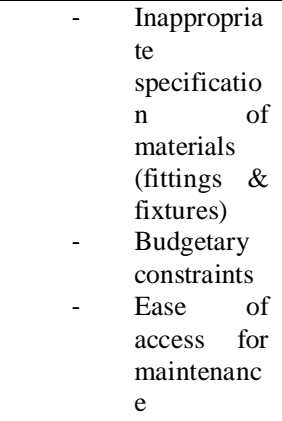 & $\begin{array}{l}\text { - Impact of non- } \\
\text { involvement of } \\
\text { FM }\end{array}$ \\
\hline
\end{tabular}




\begin{tabular}{|c|c|c|}
\hline $\begin{array}{l}\text { Contribution } \\
\text { of FM to BP }\end{array}$ & 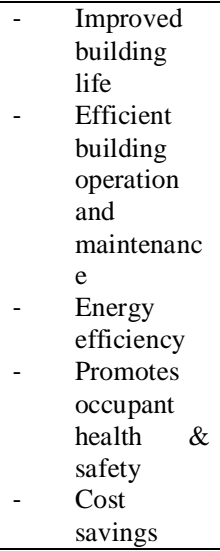 & - $\quad$ Value additions \\
\hline $\begin{array}{l}\text { Getting the FM } \\
\text { involved }\end{array}$ & $\begin{array}{ll}\text { - } & \text { Awareness } \\
\text { creation } \\
\text { - } & \text { Education } \\
\text { and training } \\
\text { - Adequate } \\
\text { compensati } \\
\text { on package } \\
\text { for FM }\end{array}$ & \\
\hline
\end{tabular}

Source: Author [2019]

\section{DISCUSSIONS}

\subsection{The Facilities Manager and the Design Stage of Buildings}

The significance of integrating the facilities managers' role at the design stage of buildings is well articulated by the responses elicited from all respondents. For instance, R5 mentions that;

"Traditionally the facilities managers' role is known when the project is deemed to be practically complete. However, with the introduction of Building Information Modelling [BIM] in projects, the role is known during all stages of a building's life cycle".

This assertion aligns with existent studies by Douglas [1996], Enoma [2005], Wang et. al. [2013] who corroborate that the involvement of facilities management function at the initial stages of the building development process has beneficial outcomes in terms of BIM, energy efficiency and sustainability.

Significantly, the Concept Design and Technical Design stages of the RIBA Plan of work [2013] are identified as the stages where the input of the facilities manager are much needed. These stages are seen to offer the facilities manager the most opportunity to make valuable inputs in terms of incorporating the operational needs of buildings such as details of specifications, materials selection, which have significant impacts on building performance. Moreover, the inclusion of the facilities manager at the Concept Design Stage is seen to enable a choice of optimal design solutions that enables optimization of performance-in-use. The Technical Design Stage is also seen as the stage where the inputs of allied professionals are sought so the inclusion of the facilities manager would not be out of place. In articulating the involvement of the FM at this stage, R2 indicates that;

"At the technical design stage, the client would have agreed to the overall design concept and hence all related professionals are brought on board to make their inputs including the FM".

According to RICS [2015], the FM at the technical design stage, the FM has the competency to offer input on the technical designs and specifications. Pilanawithana and Sandanayake [2017] also asserts that at this stage the FM reviews the technical designs with respect to life cycle costs of the building.

Although Stages 2 and 4 of the RIBA Plan of Work [2013] dominates the stages for inclusivity per the findings of this study, Stage 1 [Preparation and Brief] is also seen as another stage where the involvement of the facilities manager is required to facilitate the client's ability to properly define the required outcome of the project. Even though the findings of this study did not identify any role for the facilities manager in the other stages of the RIBA Plan of Work [2013] that pertains to the design phase of buildings, the ideas and findings of RICS [2015] and Pilanawithana and Sandanayake [2017] are worthy of consideration.

\subsection{Specific Inputs of FM at the Design Stage}

Respondents were unanimous in acknowledging that the FM has specific functions at the design stage that impacted on buildings in terms of performance. A key role identified was the specification of materials, finishes, fittings and fixtures. R2, R4, R8, R9, R10 contend that these elements integrate to make a building what it is and that the FM possess knowledge of it's in- use performance from other projects to serve as a benchmark. Jensen [2009] corroborates this function of the FM in the design process and cites it as the transfer of knowledge from the "back to the front end". Also identified was that the FM's involvement would ensure that the focus of the design team would be constantly aligned to life cycle costs for the building rather than the pursuit of other interests. R3, mentions that "FM facilitates operational ideas to be incorporated in the design from the onset" whilst R5 shares that "FM ensures that the attention of the design team is focused on required outcomes and operational performance". Additionally, the FM was identified as possessing the competences and knowledge required to provide a practical evaluation of design decisions and choices that facilitates the optimisation of resources for enhanced design solutions.

\subsection{Barriers to FM Involvement at the Design Stage}

The emergent nature of the FM as a profession is cited as a key contributory factor to the lack of involvement at the design stage by all the respondents. According to R5," the profession is viewed with suspicion and seen as a threat to the designer's preferences". R7 on the other hand shares that "...may see the FM as an interference with their work". Similarly, R4 shares that "lack of appreciation of the role of FM by other professionals". Related to this is the lack of awareness and misconception of the FM's role in the building development process which traditionally coincides with the project hand-over. R2 mentions that "lack of knowledge about the actual role of the FM in the built environment as far as clients and some allied professionals are concerned". According to R8, the FM profession "is not well recognized by other professionals", whereas R1 laments that "it is an emerging profession in Ghana and would take time for other professionals to accept". Another setback identified in relation to the involvement of the FM at the design stage is cost. The involvement of the FM is considered as an addition to the overall project costs in terms of fees for the services of consultants. R4 mentions that "the design team costs will increase". Enoma [2005] also cites cost as a barrier to the early involvement of the FM in building development. Another dimension on the issue of cost is that certain inputs of the FM will certainly require investments into systems that will add on to the cost of procuring the building. R7 expresses this sentiment "Most of the time project owners seek 
to reduce cost that may arise from the FMs input on the design of the facility". R2 also indicates that "client may not agree with the inputs from the FM since he may be constrained by budget and preferences ...."

Jensen [2009] whilst corroborating the cost implication on the involvement of the FM, calls for a holistic appraisal of the value addition of the FM over the life cycle of a building vis-à-vis its initial investment costs.

\subsection{Value Addition of FM Involvement at the Design Stage}

Respondents were unanimous in acknowledging that the involvement of the FM at the Design Stage have beneficial consequences on building outcomes and operations. The value additions on the involvement of the FM identified includes an increased building life as a result of appropriate decision making, choice of optimal design options with a focus on performance-inuse. Additionally, R2, R7, R9, R10 indicates that FM involvement promotes work place efficiency as their knowledge on ergonomics facilitates efficient utilization of space. According to R3 and R4 being equipped with knowledge of the design considerations and decisions facilitates ease of maintenance and minimizes downtimes associated with systems and equipment breakdowns. R6 and R7 states that FM involvement ensures that envisaged performance equates performance-in-use and the actualization of building efficiency. It is noteworthy to state that R1 and R8 mention that without necessary competences, the involvement of the FM would not be beneficial to the design process. In line with this, Jensen et. al. [2009] states that without appropriate competences of the FM the involvement would not yield positive effect.Gelnay [2002], Tucker et. al. [2012] Jensen et. al. [2013] cites relationship management as one of the key competences required of the FM for their involvement at the design stage. Jensen et. al. [2013] mentions the determination of facilities life cycles, prediction of future facilities operations whereas Tucker et. al. [2017] mentions knowledge management as other competences that are required of the FM to be an effective member of the design team.

\subsection{Building Performance and the Facilities Manager}

Respondents variously described building performance to connote the degree to which a building carries out its function, efficiency of use, structural stability, operability, the health and safety that a building affords its occupants. The notions and descriptions ascribed to building performance is indicative of the consistency of the absence of a definitive description of building performance expressed in studies which have sought to investigate the concept. Slopek [2013] aptly corroborate that the concept of building performance is not well understood and that the usual practice is to interchange or equate energy performance with building performance. Ibem et. al. [2013] and de Wilde [2017] affirm that the varying perspectives from which buildings are evaluated accounts for the absence of a clear cut definition. Similarly, the field of expertise of respondents largely influenced their notion of the concept. For instance, R3 [civil engineer] expresses the concept as "the building not deflecting excessively and easily...", R2 [architect] "... how the building can be enjoyed by its users efficiently and most importantly how the building can be maintained efficiently”, R4 [quantity surveyor] “...characteristics of the building to fulfil its functional, operational, needs without compromising on cost and quality, R5 [architect] "....characteristic of a building that indicates how well that building carries out its function.

\subsection{Contributions of FM in Enhancing Building Performance}

As per the findings of this interview, buildings play an essential role in facilitating the integral relationships fostered by the FM by ensuring that optimal performances are achieved. Respondents highlighted that the efficient operations of buildings in terms of energy utilization, space utilization, durability of systems, elements, fixtures and fittings, improvements to occupants' health and safety as benefits that could be harnessed from the involvement of the FM in order to optimize building performance. Further identified were the ease of maintenance of the buildings which R2 and R8 explain that being conversant with many of the buildings' features, accessibility to systems and availability of replacement parts are clearly taken care off at the onset.

\subsection{Challenges of FM in Achieving Building Performance}

The importance of the FM in enhancing building performance is acknowledged by all respondents, however, their function is saddled with challenges. R1, R4, R5 cites the lack of influence in decision making as one of the challenges that impacts on FM's ability to ensure optimal building performance. R1 explains that the lack of influence impacts on budgetary allocations required to facilitate the FM function and hence their effectiveness. R5 cites the design and construction deficiencies as the challenge in achieving efficient building performance by the FM. R8 cite "... absence of technical and professional training in the changing technological or digital world".

\subsection{Promoting the Role of FM}

In order to achieve efficient building performance through the FM function and involvement at the design stage, respondents with the exception of R1 and R8 were unanimous in advocating for the creation of awareness through sensitization, advocacy and education of allied professionals in the building development process. Similarly, Jensen et. al. [2009] affirm increased awareness creation of clients and designers in order to properly situate the FM in the design process. R1 suggests the use of value engineering in building management by FM practitioners in order to prove their relevance. R8 "...constant technical and professional training".

\section{CONCLUSION AND FUTURE SCOPE}

\subsection{Specific Roles for FM at the Design Stage}

This study focused on the design stage with regards to impacting building performance with reference to the RIBA Plan of Work [2013] which outlines the design stage as: Strategic Definition [Stage 0], Preparation and Brief [Stage 1], Concept Design [Stage2], Developed Design [Stage 3], Technical Design [Stage 4]. 
Even though all the stages have relevant FM functions, the findings of the study indicate that the FM's role was more related to the concept and technical design stages with regard to building performance. The specific FM roles identified are summarized below:

1. Leads the design team to focus on life cycle cost in the design process

2. Identifies and assists in choice of performance based design options

3. Practical evaluation of specifications and materials selection (building elements, fittings, fixtures)

4. Advising on space utilization and ergonomics

\subsection{Benefits of Involving FM at the Design Stage}

The involvement of the of the facilities manager at the design stage has beneficial consequences which this study sought to portray. Existent literature postulates that FM involvement at the design stage enables benefits for BIM, sustainability, and green concepts in buildings. Similarly, this study identifies benefits that could be derived from FM involvement at the design stage. These benefits are highlighted below:

- $\quad$ Facilitates the derivation of cost effective building designs

- Efficient management of buildings and systems

- Knowledge about design concepts and rationale facilitates ease of maintenance

- Efficient building operations [minimises the need for alterations]

The study also identified that the involvement of the FM does not necessarily correlate efficiency in building outcomes but that FM's must have appropriate competences in order to be effective at the design stage. Mohammed and Hassanain [2010] postulates that the FM should possess the requisite technical competences needed to make their involvement at the design stage beneficial.

The adoption a performance based approach in the design of buildings goes a long way in ensuring that buildings perform as intended. According to Szigeti and Davis [2005] the performance based approach of building design targets required performance and fitness for purpose from the outset of its development process.

\subsection{Recommendations}

In view of the limitations of the study, and the lack of extensive literature on the involvement of the facilities manager at the design stage, a more exploratory approach on the involvement of the FM at the design stage with regards to collaboration with other professionals in the design team should be pursued. This is to enable the development of a comprehensive framework that outlines the competences and technical expertise required of the FM to be effectively involved in the design process of buildings.

Moreover, there should be advocacy for the development of a legal framework that guarantees the mandatory inclusion of facilities management professionals in regulations and codes for buildings and projects of a certain scale as applicable to the other professionals in the National Building Regulations 1996 [L.I. 1630] in order to effectively achieve required performance.

\section{CONCLUSION}

This study investigated the involvement of the facilities manager at the design stage and sought to identify definitive roles at this stage of the building development process. The findings of the study portray that the FM has specific roles to play and that if engaged as the study seeks to postulate, there are value propositions and additions that would facilitate the optimization of a building's performance.

\section{REFERENCES}

[1] Abbas E., Czwakiel A., Valle R., Ludlow G., Shah S. [2009]. The practice of sustainable facilities management: design sentiments and knowledge chasm. Architectural engineering and design management, 51-2. Pg. 91-102 DOI: 10.3763aedm.2009.0909

[2] Amaratunga D., Baldry D.[1998]. Appraising the total perfor mance of higher educational buildings: a participatory approa ch towards a knowledge-base system. In: Proceedings of the COBRA 98 RICS (Construction and Building Research Conf erence), December 1998,

Oxford Brookes University, Oxford, UK. [Unpublished].

[3] American Council for Energy- Efficiency Economy [ND] Building Performance. Available at: https://aceee.org/topics/building-performance. Accessed on $3 / 6 / 2019$

[4] Ayres C. [2019] 18 Advantages and Disadvantages of Purposive Sampling. ConnectUS. Available at: https://www.connectusfund.org. [Accessed on 17/7/19].

[5] Bragança L., Vieira M. S., Andrade B.J [2014]. Early Stage Design Decisions: The Way to Achieve Sustainable B Building at Lower Costs. The Scientific World Journal. Vol. 2014. Available at: http//:dx.doi.org/10.1155/2014/365364. [Accessed 11/7/18].

[6] Becker, F. [1990], "Facility management: a cutting-edge field?" Property Management, Vol. 8 No. 2, pp.108-116.

[7] Bengsston M. [2016]. How to plan and perform a qualitative study using content analysis. NursingPlus Open. Vol. 2. Pg. 8-14.

[8] BIM4FM [2016], "BIM4FM say's Start with the end in mind". Available at: www.bsria.co.uk/news/article/bim4fmsays-start-with-the-end-in-mind/ (Accessed on 10/6/19).

[9] BIFM [2016], "Facilities Management Introduction". Available at: https:// www.bifm.org.uk/bifm/about/ facilities. [Accessed 20/01/19].

[10] Bordass B., Leaman A., Ruyssevelt P. [2001] Assessing building performance in use 5: conclusions and implications. Building Research \& Information. Vol.29 (2). Pg.144-157

[11] Bosch, S.J. and Pearce, A.R. (2003). Sustainability in public facilities: Analysis of guidance documents. Journal of Performance of Constructed Facilities, 17(1). Pg.9-18.

[12] Brown A., Hinks J., Sneddon J. (2001) "the facilities management role in new building procurement". Facilities. Vol. 19(3/4) Pg. 119-130. Available at: https://doi.org/10.1108/02632770110381667. (Accessed on 3/03/19).

[13] CIBSE (2016), "About the Group". Available at: www.cibse.org/networks/groups/facilitiesmanagementfm/about-the-group (accessed10/12/2018).

[14] Chohan, A.H., Che-Ani, A.R., Memon, Z., Tahir, M.M., Abdullah, N.K.G., and Ishak, N.H. (2010). "Development of user sensitivity index for design faults in low rise urban housing, a study of developing metropolitan city". American Journal of Scientific Research, 12 (1), 113-124.

[15] Creswell, J.W (2012). Educational Research: planning. Conducting and Evaluating 
[16] Creswell, J.W., Poth, C.N. (2017). Qualitative inquiry and research design: Choosing among five approaches. Sage publications.

[17] De Silva N. (2011). Promoting the facilities management profession in the project development phase of high-rise buildings in Sri Lanka. Built - Environment - Sri Lanka. Vol. 09 - 10, (1 -2). Pg.37-44.

[18] De Wilde P. (2017). The concept of building performance in building performance simulation - a critical review. Proceedings of the 15th IBPSA Conference San Francisco, CA, USA, Aug. 7-9, 2017. Pg. 1021-1026. Available at: https://doi.org/10.26868/25222708.2017.270 (accessed on $6 / 03 / 19)$

[19] De Wilde P. (2018). Building Performance Analysis. John Wiley \& Sons, 1st Ed.

[20] Denzin, N.K., 2017. Critical qualitative inquiry. Qualitative Inquiry, 23(1), pp.8-16.

[21] Douglas, J. (1996), "Building performance and its relevance to facilities management". Facilities.Vol. 4. (3/4), Pg. 23-32. Available at:https://doi.org/10.1108/02632779610112508 (accessed 23/11/18).

[22] Easterby-Smith, M., R. Thorpe, \& P. Jackson, (2012) Management Research, 4th edition, London: SAGE Publications

[23] Echenagucia T. M., Capozzoli A., Cascone Y., Sassonea M., (2015) The early design stage of a building envelope: Multiobjective search through heating, cooling and lighting energy performance analysis. Applied Energy. Vol. 154. Pg. 577591

[24] Enoma A. (2005). The role of facilities management at the design stage. In: Khosrowshahi F. (Ed.), 21st Annual ARCOM Conference, 7-9 September 2005, SOAS, University of London. Association of Researchers in Construction Management, Vol. 1, 421-30.

[25] Fadamiro J. A., Bobadoye S. (2006). Managing The Building Design Process for Sustainability and Improved Quality. Civil Engineering Dimension, Vol. 8(1) Pg. 1-7.

[26] Flick, U. (2018). An introduction to qualitative research. Sage Publications Limited.

[27] Gelnay B. (2002) Facility Management and the Design of Victorian Public Hospital. Proceedings of CIB W070 2002 Global Symposium. Pg. 525-545.

[28] Gopikrishnan S., Paul V. K. (2018). Measuring Satisfaction with User Requirement Related Building Performance Attributes: A Questionnaire. Journal of Building Performance. Vol.9 (1). Pg. 133-146

[29] Ibem E.O., Opoko A.P., Adeboyea A. B., Amoleb D. (2013) Performance evaluation of residential buildings in public housing estates in Ogun State, Nigeria: Users' satisfaction perspective. Frontiers of Architectural Research. Vol. 2, Pg.178-190

[30] Ishak, S., Chohan, A., Ramly, A. (2007). Implications of design deficiency on building maintenance at postoccupational stage. Journal of Building Appraisal. Vol. 3. (2). Pg. 115-124

[31] Jensen, P.A., (2009). Design integration of facilities management: A challenge of knowledge transfer. Architectural Engineering and Design Management, 5(3). Pg.124-135.
[32] Jensen P. A. (2008). Integration of Considerations for Facilities Management in Design. In Design Management in the Architectural Engineering and Construction Sector: CIB W096 Architectural Management \& TG49 Architectural Engineering (pp. 191-199). Rotterdam: CIB. CIB Reports, No. 319.

[33] Jensen P. A. Damgaard T., Kristiansen K. (2009). The Role of Facilities Management in Building Projects.Conference Paper. Changing Role'09 conference in the Netherlands. 6-9 October 2009.

[34] Jensen P. A., Sarasoja A-L., van der Voordt T., Coenen C. (2013) how can facilities management add value to organizations as well as to society? Conference Paper. Brisbane, Australia: CIB World Building Congress, 5-9 May 2013.

[35] Jones B. (2004) 'Perspectives On Management Research Design and Orientation: Quandaries and Choices'. Electronic Journal of Business Research Methods. Vol. 23 (2) Pg. 111118

[36] Kalay, Y. (1999). Performance-based design. Automation in Construction, 8, 395-h409

[37] Korstjens I., Moser A. (2018) Series: Practical guidance to qualitative research. Part 4: Trustworthiness and publishing, European Journal of General Practice. Vol. 24 (1). Pg. 120124. Available at; https://doi.org/10.1080/13814788.2017.1375092 (accessed on $24 / 7 / 19$ ).

[38] IEA Annex 21, 2016. Annex 21 Environmental Performance webpage [online]. Available at:http://www.ecbcs.org/annexes/annex21.htm(Accessed 04/06/2019)

[39] Knotten V., Svalestuen, F., Hansen G. K., Lædre O. (2015) Design management in the building process - A review of current literature. 8th Nordic Conference on Construction Economics and Organization. Procedia Economics and Finance 21 (2015) Pg.120 - 127

[40] Labaree R. V. (2009) organizing your social science research: qualitative methods. Available at: http://libguides.usc.edu/writingguide/qualitative (accessed 07/12/18).

[41] Lago A., Trabucco D., Wood A., (2018). Damping Technologies for Tall Buildings. Butterworth-Heinemann. ISO 19208:2016.

[42] Marshall C., Rossman G.B. (2014). Designing qualitative research. Sage publications.

[43] McAuley B., Hore A., West R., Wall, J. (2012). The Economic Case for Early Adoption of Facilities Management. Proceedings of the Joint CIB W070, W092 \& Tg72 International Conference On Facilities Management, Procurement Systems and Public Private Partnership: Delivering Value to the Community. University of Cape Town, 23-25 January, 2012.

[44] Merritt F. S., Ricketts J. T. (Ed). (2001) Building Design and Construction Handbook. McGraw-Hill $-6^{\text {th }}$ Ed.

[45] Mertler (2016). Quantitative research. Sage Publication. Available at: https://us.sagepub.com/sites/default/files/upmbinaries/70019_Mertler_Chapter_7.pdf

[46] Mohammed, M. A. \&. Hassanain, M. A. (2010). Towards Improvement in Facilities Operation and Maintenance 
Through Feedback to The Design Team. The Built Environment and Human Review. Vol. 10. Pg. 72-87

[47] Muijs D. (2004) Doing quantitative research in Education. SAGE Publications Ltd. 1 Oliver's Yard 55 City Road London EC1Y 1SP.

[48] Mustafa A. F. (2017) Performance assessment of buildings via post-occupancy evaluation: A case study of the building of the architecture and software engineering departments in Salahaddin University-Erbil, Iraq. Frontiers of Architectural Research Vol. 6, (3). Pg. 412-429

[49] Okoroh, M I, Jones, C M and Ilozor, B D (2003) Adding value to constructed facilities: facilities management hospital case study. Journal of Performance of Constructed Facilities.

[50] Pfeifer M. (2009) Materials enabled designs: The materials engineering perspective to product design and manufacturing. Butterworth-Heinemann

[51] Pilanawithana M.N., SandanayakeY. G. (2017) "Positioning the facilities manager's role throughout the building lifecycle", Journal of Facilities Management, Vol. 15 (4), Pg.376-392

[52] Potkany, M., Vetrakova, M. and Babiakova, M. (2015). Facility Management and Its Importance in the Analysis of Building Life Cycle. Procedia Economics and Finance, 26, pp.202-208

[53] RIBA (2013), "RIBA Plan of Work 2013 Overview", Available www.architecture.com/files/ribaprofessionalservices/practice /ribaplanofwork2013overview. (Accessed 24/03/19).

[54] Schoonenboom J., Johnson R. B. (2017) How to Conduct Mixed Method Research. KolnerZeitschrift Fur SoziologieUndSozialpsychologie. Available at: https://www.ncbi.nlm.nih.gov/pmc/articles/PMC5602001/. Accessed on 07/07/2019

[55] SERG (2006) What Is Good Building Performance. Sustainable Energy Research Group). University of Southampton. Available at: www.soton.ac.uk/what-is-goodbuilding-performance/ (Accessed on 16/6/19).

[56] Silverman, D. ed. (2016). Qualitative research. SAGE.

[57] Szigeti F., Davis G. (2005). Performance Based Building: Conceptual Framework. PeBBu Final Report. EUR 21990 ISBN 90-6363-051-4.

[58] Tucker M., Masuri M. R. A., Noor M., N., M. (2012) optimising the role of facilities management (FM) in the development process (DP): the development of FM-DP integration framework for sustainable property development, In Smith S. D. (Ed) Procs $28^{\text {th }}$ Annual ARCOM Conference, 3-5 September 2012, Edinburgh, UK, Association of Researchers in Construction Management. Pg. 1355-1365

[59] Tucker M., Masuri M., Cotgrave A. (2017) "Critical issues for the integration of facilities management into the development process". Property Management. Vol. 35 (4) Pg. 380-393

[60] Villanueva M., Vazquez E., Nobrega J., Miranda R., Artur Mussi J., Alves L. (2017). Evaluation of the Maintenance Management Associated with the Performance of a Public Building. Journal of Civil Engineering and Architecture 11 (2017) Pg. 448-454 Doi: 10.17265/1934-7359/2017.05.005

[61] Walliman, N. (2017). Research methods: The basics. Routledge.

[62] Wang Y., Wang X., Wang J., Yung P., Jun G. (2013) Engagement of Facilities Management in Design Stage through BIM: Framework and a Case Study. Advances in civil engineering. Vol. 2013. Article ID 189105,8 pages,2013. https://doi.org/10.1155/2013189105.

[63] Williams, B., 2006. Building performance: the value management approach. In: Clements-Croome D. (Ed.) Creating the productive workplace, $2^{\text {nd }}$ Ed. Pg.434-457.

[64] Western Michigan University (ND) Overview of the Bronco Project Process. Available at: https://wmich.edu/facilities/facilities-project-process. Accessed on 13/6/2019.

[65] Yekrangnia M., Arian S., (2019) Advanced Design Examples of Seismic Retrofit of Structures. Butterworth-Heinemann. EBook ISDN: 9780081025352

[66] Zhang Y., Wildemuth B. M. (2013). "Qualitative Analysis of content" In: Wildemuth B.M. (Ed). Applications of Social Research Methods to Questions in Information and Library Science, Libraries Unlimited. Pg. 1-12. 